\title{
Smart Repetition dan Brain Wave Technology dalam Pembuatan Audio Book Kosa Kata Bahasa Inggris
}

\author{
Raden Arfan Rifqiawan \\ Universitas Islam Negeri Walisongo Semarang
}

\begin{abstract}
Research work, devotion lecturers are embodied with mentoring activity, making audiobook and a mastery vocabulary English often used with Smart Repetition and Brain Wave technology. Making audiobook with Smart Repetition and Brain wave technology done together the participants capital. Making audiobook it is not easy that calls for exercise and patience participants capital .But through frequent exercise, finally they can make audiobook according to what they want. Assistance mastery vocabulary English often used with Smart Repetition and Brain Wave technology do with some stage.An early stage done by building community using application Telegram.The next stage is for the delivery of material, training, and the interaction continuously between researchers and participants cooperate either directly or online until the participants cooperate graduated from college.
\end{abstract}

Abstrak: Kerja Penelitian dan pengabdian dosen yang diwujudkan dengan aktivitas mentoring, membuat audiobook dan penguasaan kosakata bahasa Inggris sering digunakan dengan Smart Repetition dan teknologi Brain Wave. Membuat audiobook dengan Smart Repetition dan teknologi Brain Wave dilakukan bersama-sama peserta modal. Membuat audiobook tidak mudah yang membutuhkan latihan dan kesabaran peserta.Tapi melalui latihan yang terus-menerus, akhirnya mereka dapat membuat buku audio sesuai dengan apa yang mereka inginkan. Bantuan penguasaan kosakata bahasa Inggris sering menggunakan Smart Repetition dan teknologi Brain Wave yang dilakukan dengan beberapa tahap. Tahap awal dilakukan dengan membangun komunitas menggunakan aplikasi Telegram. Tahap berikutnya adalah untuk penyampaian materi, pelatihan, dan interaksi terus menerus antara peneliti dan peserta bekerja sama baik secara langsung 
atau online sampai peserta berhasil lulus dari perguruan tinggi.

Kata Kunci: smart repetion, teknologi brain wave, audio book

\section{PENDAHULUAN}

Pemberitaan Pembelajaran bahasa Inggris dewasa ini sangat diperlukan dalam rangka menghadapi persaingan global. Apalagi bangsa Indonesia tergabung dalam berbagai organisasi-organisasi di dunia yang menuntut semua sumber daya manusianya dapat berbahasa Inggris dengan baik dan lancar. Pembelajaran bahasa Inggris sudah dilaksanakan hampir di semua tingkatan mulai, pendidikan taman kanak-kanak (TK), sekolah dasar/madrasah ibtidaiyah (SD/MI), sekolah menengah pertama (SMP), sekolah menengah atas (SMA), dan perguruan tinggi (PT).

Meskipun pengajaran bahasa Inggris sudah dilakukan sejak TK sampai perguruan tinggi, keberanian membiasakan penggunaannya masih belum berhasil pada banyak orang. Salah satu penyebabnya karena miskinnya kosa kata yang dikuasai.

Menghafal kosa kata bahasa asing merupakan pekerjaan yang susah dan membosankan, namun sekarang ada beberapa metode untuk menghafalkan kosa kata. Seseorang akan dianggap fasih berbahasa Inggris apabila sudah menguasai 3000 kata. Menurut Longman Institute seseorang dapat menguasai Bahasa Inggris dengan benar harus memiliki syarat utama, yaitu menguasai 3000 Kosakata yang sering dipakai dalam percakapan (bigh frequency words in use). ${ }^{1}$ Namun untuk berani membiasakan penggunaannya dari 3000 kata itu bisa diringkas lagi 1000 kata bahkan kurang dari itu.

Metode dalam menguasai kosa kata bahasa Inggris bisa menggunakan flash card, metode membaca keras, metode audiovisual. Dalam karya pengabdian ini peneliti akan menggunakan metode baru dalam penguasaan kosa kata bahasa asing, yaitu metode Spaced Repetition atau yang lebih dikenal dengan Smart Repetition dan Brain Wave Technology. Metode Spaced Repetition adalah sebuah metode menghafal kata dengan cara pengulangan berjeda, ${ }^{2}$ sedangkan Brain

1 Jeremy Harmer, Longman Communication 3000, Longman Dictionary of Contemporary English Series, Harlow: Pearson Education, 2007. hlm. 1.

2 Raden Arfan Rifqiawan, "Pembuatan Flash Card Digital untuk Pembelajaran 80\% Kosa Kata Al- Qur'an" dalam Jurnal at-Taqaddum, Volume 8, Nomor 1, Juli 2016, hlm. 27. 
Wave Technology merupakan aktivasi otak yang dilakukan berulan-ulang/rhythmic dalam jangka waktu tertentu yang dapat berupa stimulasi visual dan auditory. ${ }^{3}$ Kedua metode ini bertujuan memasukkan kosa kata bahasa Inggris ke dalam pikiran bawah sadar sehingga tidak mudah lupa. Cara penggunaan metode ini pun sangat mudah, bisa menghafal banyak kosa kata sambil bekerja, di pasar, di mall, di mana saja. Hasil pengabdian akan di-share kepada masyarakat, yaitu kalangan akademik dan umum, dimintakan feedback untuk perbaikan.

Adapun permasalahan yang timbul dari latar belakang di atas adalah bagaimana pembuatan audiobook menguasai kosa kata bahasa inggris yang sering digunakan dengan Smart Repetition dan Brain Wave Technology, serta bagaimana pendampingan penguasaan kosa kata bahasa Inggris yang sering digunakan dengan Smart Repetition dan Brain Wave Technology.

Adapun tujuan dari penelitian ini adalah terwujudnya audiobook menguasai kosa kata bahasa inggris yang sering digunakan dengan Smart Repetition dan Brain Wave Technology serta terlaksananya pendampingan penguasaan kosa kata bahasa Inggris yang sering digunakan dengan Smart Repetition dan Brain Wave Technology.

Sedangkan ignifikansi penelitian ini adalah hasil dari penelitian dapat menjadi alat untuk penunjang dalam pembelajaran bahasa Inggris dan juga bermanfaat sebagai referensi dalam penelitian teknologi pembelajaran, interaksi dosen mahasiswa, dan partisipasi mahasiswa.

\section{ALAT BANTU BELAJAR BAHASA INGGRIS}

Longman Comunication 3000 adalah daftar 3000 kosa kata bahasa Inggris yang paling sering digunakan secara lisan dan tulisan yang diambil berdasarkan analisis statistik dari 390 juta kata yang terkandung dari database bahasa Inggris yang dimiliki Longman Pearson Education di London, Inggris. Database tersebut berisi bahan-bahan bahasa yang terkumpul dalam suatu sumber yang disebut korpus atau sejenis bank bahasa yang berasal dari penggunaan bahasa dalam berbagai genre, ragam, dan bahan lisan maupun tertulis yang menjamin keragaman yang seluas-luasnya dan menghindari penggunaan bahasa yang sangat sempit seperti idiolek. Data tersebut disusun secara sistematis dan mudah diakses secara elektronis dengan komputer. Metode ini digunakan dalam linguistik deskriptif maupun linguistik terapan, seperti penyusunan kamus, untuk menjamin bahwa data yang digunakan benar-benar berasal dari penggunaan yang luas dan terhindar dari penggunaan subjektif. Longman

3 Tianbao Zhuang, "A Study of Brainwave Entrainment Based on EEG Brain Dynamics" in CSCE Computer and Information Science Journal, Vol. 2, No.2, May, 2009, hlm. 81. 
Comunication 3000 merupakan inti dari bahasa Inggris dan berguna bagi para pelajar untuk belajar berkomunikasi secara efektif baik lisan dan tulisan. ${ }^{4}$

100 Word to Make You Sound Smart adalah daftar kosa kata yang disusun oleh para editor dari American Heritage Dictionaries. Merupakan 100 kosa kata untuk membuat seseorang terlihat cerdas dalam komunikasi lisan. Kosa kata tersebut dapat digunakan untuk wawancara, memberikan pidato di sebuah pesta pernikahan, menghadiri acara, atau, membuat orang tertarik karena seseorang yang menggunakannya akan terlihat berpendidikan tinggi. ${ }^{5}$

Berbagai jenis kosa kata telah dipilih, termasuk kata-kata berguna dari hanya satu suku kata (seperti kata glib) dan kata-kata yang berasal dari namanama orang-orang terkenal seperti Freudian Slip dan Machiavellian. Ada ekspresi dari budaya populer (seperti kata Catch-22) dan kata-kata yang yang berasal dari peradaban klasik (seperti spartan dan stoic). Setiap kata dan ditampilkan contohnya dalam dalam konteks dengan kutipan dari majalah, buku, surat kabar, film, acara TV, dan pidato.

Kursus Inggris "Carakita.Com" atau yang dikenal dengan nama situsnya www.carakita.com adalah bagian dari Lembaga Kursus Inggris yang berlokasi di Denpasar, Bali. "Carakita.Com" online pada tanggal 15 Desember 2006, khusus untuk menangani pengajaran Bahasa Inggris secara online melalui internet.

"Carakita.Com" didirikan pada tanggal 9 Juli 2002. Mulai saat berdiri hingga 2011 hanya mengkhususkan diri memberikan pelajaran Bahasa Inggris secara privat dan semi privat, baik di tempat kami ataupun di rumah masingmasing peserta. Metode yang digunakan adalah metode khusus ala Indonesia, yang disusun dan dikembangkan sangat berbeda dari metode pangajaran Bahasa Inggris yang digunakan selama ini.

Melihat antusiasme para pelajar yang begitu besar terhadap materi dan cara pengajarannya, akhirnya kursus tersebut ditampilkan secara online agar bisa digunakan secara luas di seluruh wilayah Indonesia. Tujuannya adalah menyediakan alternatif cara pengajaran Bahasa Inggris yang mudah, murah, serta tidak terikat tempat dan waktu; sehingga nantinya semua orang Indonesia dapat belajar Bahasa Inggris dalam waktu yang singkat."Carakita.Com" memilihkan daftar kosa kata sebagai penunjang belajar. Adapun daftar kosa katanya adalah sebagai berikut: ${ }^{6}$

\footnotetext{
${ }^{4}$ Jeremy, Longman ..., hlm. 2-16.

5 The Editors of American Heritage Dictionaries, 100 Word to Make You Sound Smart, Boston : Houghton Mifflin Company, 2006, hlm. iv.

6 http:/ / www.carakita.com
} 
Ada beberapa cara yang dapat dilakukan oleh seorang pengajar untuk meningkatkan konsentrasi dan menjaga daya ingat serta daya kreativitas peserta didik. Salah satu caranya ialah dengan melakukan terapi gelombang otak atau dalam bahasa yang lebih universal dikenal dengan nama terapi Brainwave Entrainment. Jaringan otak manusia menghasilkan gelombang listrik yang berfluktuasi (naik-turun). Gelombang listrik yang berfluktuasi ini disebut dengan gelombang otak (brainwave).

Gelombang otak (dalam bahasa Inggris disebut brainwave) merupakan gelombang otak yang kompleks, ditimbulkan sebagai akibat aktivitas impuls listrik di dalam otak dengan besaran (amplitudo) tidak lebih dari $200 \mu \mathrm{V}$ (mikrovolt atau sepersejuta volt) pada kisaran frekuensi 0,5 Hz sampai dengan $200 \mathrm{~Hz}$ yang merupakan gambaran dan sikap mental seseorang. Semakin tinggi aktivitas mental seseorang (keadaan sadar, fokus dan bersemangatnya) maka akan semakin tinggi kisaran frekuensi $(\mathrm{Hz})$ gelombang di dalam otaknya, namun semakin rendah impuls listrik $(\mu \mathrm{V})$ dalam otaknya. Sebaliknya, semakin rendah aktivitas mental seseorang (keadaan santai, rileks atau tidur) maka kisaran frekuensi $(\mathrm{Hz})$ gelombang dalam otak akan semakin rendah, akan tetapi impuls listrik $(\mu \mathrm{V})$ dalam otak akan semakin tinggi. ${ }^{7}$ Misalnya seseorang yang sedang rileks, bersantai, dan perenungan suatu pemecahan masalah maka gelombang otaknya berada pada kisaran $8 \mathrm{~Hz}-12 \mathrm{~Hz}$ atau biasa kita sebut berada pada pola gelombang alpha $(\alpha)$. Sedangkan ketika kita sedang berkonsentrasi tinggi, melakukan persiapan ujian ataupun melakukan suatu presentasi maka gelombang otak kita berada pada kisaran $12 \mathrm{~Hz}-16 \mathrm{~Hz}$ atau biasa kita sebut berada pada pola gelombang beta $(\beta)$.

Terapi gelombang otak mulai menjadi alat untuk menstimulasi (merangsang) fenomena tertentu di otak dimulai sekitar tahun 1960-an. Hal tersebut dilakukan oleh M.S. Sadove, MD, direktur anestesiologi di University of Illionis, terapi gelombang otak tersebut digunakan sebagai cara anestesi (pembiusan) menggunakan stimulasi yang berhubungan dengan cahaya untuk mengurangi takaran pembiusan saat operasi. Salah satu artikel pada majalah Scientific American edisi 1973, yang membahas penelitian tentang cara menggabungkan dua nada murni yang dapat menghasilkan beat (ketukan) berirama, penelitian tersebut dilakukan oleh Dr Gerald Oster (seorang ahli biofisika) asal Haiti. ${ }^{8}$

${ }^{7}$ Gunawan, Djohan. Kedabsyatan dan Kekuatan Gelombang Otak. Cet. I; Jakarta : PT. Elex Media Komputindo, 2011. hlm.1.

${ }^{8}$ Mustajib, Ajib. Rahasia Dahsyat Terapi Otak. Audio MP3. Cet. I; Jakarta : Wahyu Media, 2010. hlm. 3-4. 
Menurut hasil penelitian yang dilakukan oleh Oster tersebut, disebutkan bahwa ketukan dibagi menjadi 2 jenis, yakni binaural beat (memerlukan otak untuk memproses frekuensi yang diterima) dan monaural beat (tidak memerlukan otak untuk memproses kembali frekuensi yang diterima). Setelah membandingkan kedua beat tersebut, Oster mencatat bahwa monaural beat menunjukkan respons aktivitas listrik pada saraf yang sangat kuat. Sedangkan binaural beat menghasilkan respons aktivitas listrik pada saraf yang sangat sedikit (karena kedalamannya hanya $3 \mathrm{db}$ atau 1/10 volume berbisik).

Kemudian pada tahun 90-an studi gelombang otak ini pun dilanjutkan oleh Dr. Russell dan Dr. Carter (dokter spesialis asal Amerika yang menangani anak hyperaktif). Mereka menggunakan tekhnologi gelombang otak untuk mengeksplorasi anak hyperaktif (ADHD = Attention Deficit Hyperactivy Disorder) dan anak yang mengalami gangguan belajar.

Berdasarkan penjelasan di atas, dapat disimpulkan bahwa terapi gelombang otak telah populer dari dulu hingga kini, baik di dunia maya ataupun nyata. Sebab, manfaatnya memang sangat banyak. Misalnya, untuk kesehatan atau kecerdasan. Oleh karena itu dengan diterapkannya terapi gelombang otak atau dalam bahasa universalnya dikenal dengan terapi Brainwave Entrainment, maka diharapkan dapat memberikan pengaruh positif terhadap hasil belajar dan peserta didik dapat mencapai ketuntasan belajar.

\section{METODE MENGHAFAL KOSA KATA}

Metode Spaced Repetition adalah sebuah metode menghafal kata dengan cara pengulangan berjeda. Metode ini ditemukan oleh Hermann Ebbinghaus, seorang psikolog pada abad ke-19. Dia menemukan bahwa semakin sering manusia mengulang suatu informasi, ia akan lebih lama mengingat hal itu dan dengan demikian akan lebih lama pula jeda yang harus ada di antara pengulangan informasi. Ia kemudian mengetes dirinya sendiri dengan mencoba menghafal silabel tiga huruf yang tak ada artinya, dijedakan antara 20 menit hingga 31 hari. Penemuannya kemudian ia tuliskan di dalam Memory: A Contribution to Experimental Psychology tahun $1885 .{ }^{9}$

Salah satu penemuannya adalah forgetting curve, atau kurva pelupaan, yang menunjukkan relasi antara keterlupaan dan waktu. Nampak bahwa memori jangka panjang ternyata sangat stabil, dan untuk seseorang mengingat sesuatu dalam waktu yang lama tak diperlukan pengulangan yang ditumpuk dalam satu

${ }^{9}$ Herman Ebbinghaus, (tr. Ruger, Henry; Busenius, Clara), "Memory: A Contribution to Experimental Psycbology", Columbia University Press, New York, 1885. hlm. 33. 
waktu, tapi lebih kepada pengulangan setelah jeda yang optimum, pada waktu yang tepat.

Prinsip tersebut kemudian dikembangkan menjadi sistem penghafal tersendiri, sebuah cara untuk mengingat banyak hal dalam tempo yang paling singkat namun dengan efektivitas paling tinggi. Prinsipnya sederhana: berdasar pada penemuan di atas, dapat ditarik bahwa manusia hanya perlu mengulang informasi yang ingin ia ingat dalam jeda yang optimal, yaitu tepat pada ingatannya 90\%. Memori yang diulang tersebut kemudian akan bertahan lebih lama dari sebelumnya, dan dengan demikian informasi tersebut tak perlu diulang lagi untuk waktu yang lebih lama dari sebelumnya.

Pada tahun 1939, penelitian oleh H.F. Spitzer menguji efektifitas sistem pengulangan berjeda pada 3.600 orang murid di Iowa yang mempelajari faktafakta sains. Hasil uji Spitzer menunjukkan bahwa sistem ini efektif. ${ }^{10}$

Di zaman dahulu, ketika belum ada komputer pribadi modern, orang dapat menggunakan metode ini dengan kartu-kartu kertas berisi informasi yang hendak diingat. Kartu-kartu itu kemudian disortir dan dimasukkan ke tiga amplop yang berbeda. Masing- masing amplop merepresentasikan jeda yang berbeda. Amplop pertama, misalnya, bertuliskan 10 menit, digunakan untuk kartu yang baru akan diingat dan dengan demikian akan terlupakan paling cepat. Amplop kedua, 1 hari, berisi kartu-kartu yang informasinya sudah dapat diingat hingga keesokan harinya. Begitu seterusnya dan jedanya akan terus memanjang hingga seminggu, sebulan, bahkan setahun. Namun begitu, sistem kartu ini tidak ergonomis karena dibutuhkan ribuan kartu kertas untuk menghafal ribuan informasi.

Pada saat ini, amplop-amplop itu telah digantikan oleh perangkat lunak gratis maupun berbayar yang dapat diinstal di komputer dan disinkronisasi di perangkat Android atau iDevice. Ada banyak aplikasi-aplikasi tersebut, misalnya Supermemo, Anymemo dan Mnemosyne, namun yang penulis pernah menggunakan dan akrab adalah Anymemo, perangkat lunak spaced repetition open-source yang gratis. Beberapa situs pembelajaran bahasa, misalnya Duolingo, menggunakan metode spaced repetition untuk hafalan kata. Skritter, jasa berbayar, menggunakan spaced repetition untuk hafalan karakter Cina.

Tidak hanya dalam bahasa, sistem ini pun memiliki aplikasi dalam bidang pengetahuan lain yang membutuhkan memorisasi yang kuat, misalnya matematika dan fisika (untuk rumus-rumus), biologi (peta anatomi),

${ }^{10}$ H.F. Spitzer, Studies in Retention, Journal of Educational Psychology,1939, hlm. 641-657. 
kedokteran, farmasi, hingga peta-peta geografis; karena konsep dasarnya tetap sama apapun informasi yang hendak diingat.

Adalagi Brainwave Generator. Sebuah software yang dirancang untuk menciptakan gelombang tertentu yang dapat merangsang otak. Bukan cuma itu, Gelombang yang diciptakan dari software ini dapat digunakan untuk menyembuhkan penyakit dan relaksasi. Cara penggunaannya sangat mudah. Hanya tinggal duduk rileks dan mendengarkan gelombang tersebut. Mendengarkannya bisa dengan headphone ataupun tidak asal pendengar bisa konsentrasi pada gelombang tersebut dan tidak terganggu oleh suara - suara yang lain.

Namun Brainwave Generator tidak boleh diperdengarkan kepada orang yang menderita epilepsi, menggunakan alat pacu jantung, sedang mengendarai kendaraan bermotor. ${ }^{11}$ Brainwave Generator adalah adalah software berbayar, namun untuk penelitian ini cukup dengan menggunakan trialnya selama 30 hari.

NextUp TextAloud adalah software yang dapat mengkonversi teks ke suara ataupun MP3 yang dapat di putar di PC ataupun MP3 Player. NextUp TextAloud adalah software yang mengarah ke fungsi seperti untuk pidato atau lainya dengan berbagai jenis suara premium yang bagus.

NextUp TextAloud dapat membaca teks dari email, halaman web, laporan dan banyak lagi, dengan lantang atau keras pada PC kita. TextAloud juga dapat menyimpan hasilnya untuk bacaan harian kita sebagai MP3 atau Windows Media file yang siap untuk di putar pada iPod, PocketPC, atau bahkan di TV dengan Tivo's Home Media Option. ${ }^{12}$

Next Up TextAloud adalah software berbayar, namun untuk penelitian ini cukup dengan menggunakan trialnya selama 30 hari.

\section{PERUBAHAN STRUKTURAL FUNGSIONAL MASYARAKAT}

Talcott Parson mengatakan seperti halnya teoretisi neoevolusi lainnya, menunjukkan adanya perkembangan masyarakat tradisional. Menurut Parsons, masyarakat akan berkembang melalui tiga tingkatan utama yaitu primitif, intermediate, dan modern. Dari tiga tahapan ini, oleh Parsons dikembangkan lagi ke dalam sub klasifikasi evolusi sosial sehingga menjadi lima tingkatan yaitu primitif, advanced primitif and arcchaic, historic intermediate, seedbed societies, dan modern societies.

11 http:/ / wnw.bwgen.com

12 http:/ / www.nextup.com 
Parsons meyakini bahwa perkembangan masyarakat berkaitan dengan perkembangan keempat unsur subsistem utama yaitu kultural (pendidikan), kehakiman (integrasi), pemerintahan (pencapain tujuan), dan ekonomi (adaptasi).

Tolok ukur yang digunakan Parsons untuk mendeteksi dan sekaligus membedakan tingkatan perubahan masyarakat(5 tingkatan) adalah artikulasi pengembangan fungsi integrasinya. Puncak perkembangan terpenting terhadap fungsi integrasi ini adalah ditemukan bahasa tulisan dan kunci terhadap sambungan proses evolusi sosial. Penemuan simbol komunikasi bahasa menandai fase transisi dari masyarakat primitif ke tingkat intermediate. Sedangkan penemuan hukum formal menandai fase transisi dari intermediate ke masyarakat maju (advanced).

Talcott Parsons melahirkan teori fungsional tentang perubahan. Seperti para pendahulunya, Parsons juga menganalogikan perubahan sosial pada masyarakat seperti halnya pertumbuhan pada mahkluk hidup. Komponen utama pemikiran Parsons adalah adanya proses diferensiasi. Parsons berasumsi bahwa setiap masyarakat tersusun dari sekumpulan subsistem yang berbeda berdasarkan strukturnya maupun berdasarkan makna fungsionalnya bagi masyarakat yang lebih luas. Ketika masyarakat berubah, umumnya masyarakat tersebut akan tumbuh dengan kemampuan yang lebih baik untuk menanggulangi permasalahan hidupnya. Dapat dikatakan Parsons termasuk dalam golongan yang memandang optimis sebuah proses perubahan.

Bahasan tentang struktural fungsional Parsons akan diawali dengan empat fungsi yang penting untuk semua sistem tindakan. Suatu fungsi adalah kumpulan kegiatan yang ditujukan pada pemenuhan kebutuhan tertentu atau kebutuhan sistem. Parsons menyampaikan empat fungsi yang harus dimiliki oleh sebuah sistem agar mampu bertahan, yaitu: ${ }^{13}$ a) Adaptasi, artinya sebuah sistem hatus mampu menanggulangu situasi eksternal yang gawat. Sistem harus dapat menyesuaikan diri dengan lingkungan. b) Pencapaian, artinya sebuah sistem harus mendefinisikan dan mencapai tujuan utamanya. c) Integrasi, artinya sebuah sistem harus mengatur hubungan antar bagian yang menjadi komponennya. Sistem juga harus dapat mengelola hubungan antara ketiga fungsi penting lainnya. Dan d) Pemeliharaan pola, artinya sebuah sistem harus melengkapi, memelihara dan memperbaiki motivasi individual maupun pola-pola kultural yang menciptakan dan menopang motivasi.

13 Dadang Supardan, Pengantar Ilmu Sosial: Sebuah Kajian Pendekatan Struktural. Jakarta: Bumi Aksara, 2011, hlm.154. 
Keempat fungsi tersebut dikenal dengan sebutan AGIL yaitu Adaptasi (A[adaptation]), pencapaian tujuan (G[goal attainment]), integrasi (I[integration]), dan latensi atau pemeliharaan pola (L[latency]).

Talcott Parsons adalah seorang sosiolog kontemporer dari Amerika yang menggunakan pendekatan fungsional dalam melihat masyarakat, baik yang menyangkut fungsi dan prosesnya. Pendekatannya selain diwarnai oleh adanya keteraturan masyarakat yang ada di Amerika juga dipengaruhi oleh pemikiran Auguste Comte, Emile Durkheim, Vilfredo Pareto dan Max Weber. Hal tersebut di ataslah yang menyebabkan Teori Fungsionalisme Talcott Parsons bersifat kompleks.

Teori Fungsionalisme Struktural mempunyai latar belakang kelahiran dengan mengasumsikan adanya kesamaan antara kehidupan organisme biologis dengan struktur sosial dan berpandangan tentang adanya keteraturan dan keseimbangan dalam masyarakat. Berdasarkan karya-karya Parsons, seperti empat sistem tindakan dan imperatif fungsional mengundang tuduhan bahwa ia menawarkan teori struktural yang tidak mampu menangani perubahan sosial. Hal ini dikarenakan, ia peka terhadap perubahan sosial, namun ia berpendapat bahwa meskipun studi perubahan diperlukan, tapi itu harus didahului dengan studi tentang struktur masyarakat.

Pendekatan yang dipakai dalam penelitian ini adalah riset aksi. Di antara nama- namanya, riset aksi sering dikenal dengan PAR atau Participatory Action Research. Adapun pengertian riset aksi menurut Corey (1953) adalah proses di mana kelompok sosial berusaha melakukan studi masalah mereka secara ilmiah dalam rangka mengarahkan, memperbaiki, mengevaluasi keputusan dan tindakan mereka. ${ }^{14}$

Pada dasarnya, PAR merupakan penelitian yang melibatkan secara aktif semua pihak-pihak yang relevan (stakeholders) dalam mengkaji tindakan yang sedang berlangsung (di mana pengamalan mereka sendiri sebagai persoalan) dalam rangka melakukan perubahan dan perbaikan ke arah yang lebih baik. Untuk itu, mereka harus melakukan refleksi kritis terhadap konteks sejarah, politik, budaya, ekonomi, geografis, dan konteks lain-lain yang terkait. Yang mendasari dilakukannya PAR adalah kebutuhan kita untuk mendapatkan perubahan yang diinginkan.

PAR terdiri dari tiga kata yang selalu berhubungan seperti daur (siklus), yaitu partisipasi, riset, dan aksi. Artinya hasil riset yang telah dilakukan secara partisipatif kemudian diimplementasikan ke dalam aksi. Aksi yang didasarkan

14 Yunus Abidin, Metode Penelitian, Bandung: PT. Tarsito Bandung, 2009, hlm. 105. 
pada riset partisipatif yang benar akan menjadi tepat sasaran. Sebaliknya, aksi yang tidak memiliki dasar permasalahan dan kondisi subyek penelitian yang sebenarnya akan menjadi kontraproduktif. Namun, setelah aksi bukan berarti lepas tangan begitu saja, melainkan dilanjutkan dengan evaluasi dan refleksi yang kemudian menjadi bahan untuk riset kondisi subyek penelitian setelah aksi. Begitu seterusnya hingga kemudian menjadi sesuatu yang ajeg. Oleh Stephen Kemmis proses riset aksi digambarkan dalam model cyclical seperti spiral. Setiap cycle memiliki empat tahap, yaitu rencana, tindakan, observasi, dan refleksi. ${ }^{15}$

Tahapan-tahapan dalam penelitian ini secara berurutan meliputi: a) Pemetaan Wilayah, yaitu pemetaan letak geografis (jalan, pintu masuk, letak), demografis (sosial budaya setempat), Kantor-kantor strategis (kantor polisi, RS, rumah tokoh masyarakat/tokoh agama, dll), aktor-aktor penting dan relasi sosial (pihak pro, kontra dan netral). b) Analisa Risiko (peneliti dan kontak/sekutu). Risiko antara lain kriminalisasi, pengusiran, penyuapan, konflik horizontal, pencurian, perampokan, kekerasan, penculikan dan penghilangan nyawa. c) Turun ke komunitas/lapangan. d) Mendekati kontak atau membangun sekutu strategis. e) Pengumpulan data (wawancara, observasi, dll). f) Membuat analisa kasus struktural. g) Menyusun rencana aksi. h) Melakukan aksi berupa: Sosialisasi tentang pendambingan, Pelibatan peserta dalam pembuatan audiobook, Pelibatan peserta secara aktif dalam pendampingan. Dan i) Evaluasi.

\section{HASIL KEGIATAN}

Mahasiswa yang didampingi di dalam pembuatan audiobook diharapkan menguasai kosa kata bahasa Inggris yang sering digunakan dengan Smart Repetition dan Brain Wave Technology sedang duduk di semester 6. Mereka ratarata sudah pada tahap menjelang pengajuan judul skripsi. Mereka dihadapkan juga untuk lulus tes TOEFL dengan score yang disyaratkan Universitas untuk bisa diwisuda. Berdasarkan hasil sharing, sebagian kecil mereka telah mengikuti berbagai kursus bahasa Inggris, baik di Semarang maupun sampai luar kota seperti di Pare. Namun sebagian besar merasa khawatir, karena belum mempersiapkan apapun.

Dampingan terdiri dari mereka yang saat ini sedang duduk pada semester genap 2015/2016 yaitu sebanyak 10 kelas pada jurusan Hukum

15 LPM IAIN Sunan Ampel Surabaya, Modul Pelatihan Kuliah Kerja Nyata (KKN) Transformatif LAIN Sunan Ampel Surabaya, Surabaya : LPM IAIN Sunan Ampel, 2008, hlm. 27. 
Ekonomi Islam (Muamalah), Fakultas Syariah dan Hukum UIN Walisongo dengan jumlah total 334 mahasiswa.

Mereka tertarik dengan alat bantu belajar yang digunakan peneliti dalam menyampaikan materi kuliah, diantaranya pembuatan materi kuliah secara audio, pengenalan brainwave dalam perkuliahan. Alat bantu belajar tersebut telah digunakan oleh peneliti dalam menyampaikan mata kuliah Akuntansi Syariah.

Mereka mengeluhkan jumlah kosa kata bahasa Inggrisnya masih minim, jadi belum percaya diri untuk menghadapi tes TOEFL. Peneliti menawarkan pelatihan bahasa Inggris dari carakita.com yang memang peneliti sudah menjadi membernya sudah lama. Di dalam pelatihan tersebut terdapat daftar kosa kata yang sudah dipilihkan sebagai pembantu belajar, sehingga sambil belajar akan menguasai kosa kata juga. Sebetulnya pelatihan tersebut merupakan pelatihan berbayar dengan cukup membayar Rp. 30.000,- untuk selamanya. Namun pelatihan tersebut dapat dibagikan untuk kalangan sendiri, khususnya dalam penelitian ini dan tidak boleh diperjual belikan.

Dari diskusi yang terjadi selama kuliah diputuskan untuk diadakan pendampingan penguasaan kosa kata bahasa Inggris yang sering digunakan dengan Smart Repetition dan Brain Wave Technology.

Rencana pendampingan penguasaan kosa kata bahasa Inggris yang sering digunakan dengan Smart Repetition dan Brain Wave Technology ditanggapi dengan antusias oleh mahasiswa, meskipun tidak semuanya. Dari 334 mahasiswa hanya 64 yang berminat. Selain itu sempat ada beberapa kekhawatiran mengenai tidak diperbolehkannya penggunaan brainwave untuk diperdengarkan kepada orang yang menderita epilepsi, menggunakan alat pacu jantung, sedang mengendarai kendaraan bermotor, tetapi kemudian dijelaskan bahwa pembuatan audiobook dapat dilakukan dengan menghilangkan brain wavenya.

Langkah awal dilakukan dengan membangun komunitas pendampingan. Mahasiswa yang berminat diajak bergabung ke aplikasi Telegram. Telegram merupakan aplikasi untuk berkomunikasi dengan kemampuan mengirim file ukuran besar hingga 1,5 GB. Aplikasi ini dapat dipasang baik pada smartphone maupun PC. Saat ini sudah tersedia Telegram untuk Android, Ipad, Windows Phone, Windows dan Linux.

Semula ada kesulitan dalam menginstall aplikasi tersebut di beberapa smartphone yang dimiliki mahasiswa, namun setelah menghapus aplikasi yang tidak perlu sehingga tidak full memory di kartu SD, kesulitan tersebut teratasi. Selain itu aplikasi Telegram juga di-install pada laptop yang dimiliki mahasiswa. 
Dalam tahap awal telah bergabung 68 mahasiswa yang beminat dalam kegiatan pendampingan ini. Namun kemudian 6 mahasiswa meninggalkan grup. Setelah dikonfirmasi ternyata mahasiswa yang meninggalkan grup itu tidak disebabkan karena keinginan untuk mengundurkan diri, tetapi karena salah klik di aplikasi yang mngakibatkan keluar dari grup. Mereka akhirnya bergabung kembali ke dalam grup.

Agar tujuan kegiatan pendampingan dapat tercapai dengan baik, maka perlu melakukan pendekatan yang lebih intensif kepada peserta yang menjadi komting kelas, anggota BEM, atau yang pada saat pendampingan sering melakukan konsultasi judul skripsi dengan peneliti.

Para sekutu strategis inilah yang membantu para peserta berkumpul dalam pendampingan jika diperlukan. Mereka membantu membagikan materi pelatihan yang memiliki ukuran file besar, jika para peserta kesulitan mendownload melalui aplikasi Telegram. Selain itu mereka membantu memberikan info-info kepada seluruh peserta secara serentak, karena tidak semua peserta aplikasi Telegram-nya selalu pada kondisi online.

Pembentukan sekutu strategis ini dapat berjalan dengan lancar, karena para sekutu strategis telah mengenal peneliti pada kuliah-kuliah semester sebelumnya.

Kosa-kata yang akan dibuat audiobook-nya terdiri dari 394 kata kerja, 214 kata sifat, dan 250 kata keterangan, kata depan, dan kata penghubung. File daftar kosa kata tersebut semula berformat .pdf, kemudian dikonversi ke dalam bentuk .xlsx agar mudah direkayasa database-nya. Pengolahan database dengan menggunakan metode Smart Repetition dilakukan dalam bentuk .xlsx. Setelah file jadi, kemudian dibuat bisa bersuara menggunakan aplikasi Nextup TextAload. Sebelum audio book dieksekusi dapat ditambahkan gelombang alfa pada beckground audio. Gelombang alfa dibuat melalui rekaman pada Brainwave Generator. Selain itu dapat pula ditambahkan instrumen musik Shalawat Badar. Penambahan efek brain wave maupun musik dalam audiobook merupakan pilihan, dapat dilakukan ataupun tidak.

Penyampaian materi kursus dilakukan selama satu minggu untuk peserta yang berminat dari 10 kelas yang diampu peneliti. Kegiatan dilakukan dengan memanfaatkan waktu-waktu kosong di sela-sela kuliah. Kegiatan ini bersifat interaktif, para peserta bias memberikan masukan agar proses pendampingan ini berjalan secara efektif dan efisien. Kendala-kendala yang ada selama pendampingan didiskusikan bersama agar ada solusinya.

Setelah sesi penyampaian materi proses pendampingan akan terus berlangsung sampai para peserta lulus kuliah. Kendala lokasi dan komunikasi 
dapat diatasi dengan aplikasi Telegram. Karena yang disampaikan merupakan materi pelatihan yang bersifat mandiri, maka dibutuhkan partisipasi aktif seluruh peserta untuk tercapainya tujuan kegiatan ini.

Dari hasil turun ke komunitas dan membangun sekutu strategis diketahui bahwa mahasiswa memang menginginkan kegiatan pendampingan. Peserta menyatakan teknologi audiobook, smart repetition dan brain wave patut dicoba, karena mereka pernah menerima materi kuliah Akuntansi Syariah dengan teknologi tersebut. Pada mata kuliah Akuntansi Syariah mereka diberi tugas untuk membuat audiobook jurnal-jurnal Akuntansi Syariah sesuai dengan PSAK Syariah No. 101-106. Audiobook dibuat dengan merekam suara mereka sendiri dengan alat perekam suara digital yang ada di smartphone dan mendengarkannya kembali secara repetisi. Pada saat itu brain wave dan iringan music masih terpisah, tidak seperti audiobook pada kegiatan pendampingan ini dimana audiobook, smart repetition, dan brain wave telah dimix jadi satu.

\section{ANALISIS PERUBAHAN STRUKTUR SOSIAL DAMPINGAN}

Sesuai dengan Teori dari Talcott Parsons tentang perubahan struktural fungsional dampingan, kegiatan ini dapat dipetakan sebagai berikut. Pertama, Adaptasi. Para peserta pendampingan harus bisa sungguh-sungguh memanfaatkan teknologi pembelajaran yang memang diinginkan berdasarkan hasil sharing dengan peneliti. Kedua, Pencapaian tujuan. Audiobook yang dibuat dengan Teknologi Smart Repetition dan Brain Wave diharapkan mampu membantu peserta pendampingan untuk menguasai kosa kata bahasa Inggris dan mengingatnya lebih lama. Ketiga, Integrasi. Para peserta dampingan harus bahu aktif, saling mengingatkan dan memotivasi diantara para peserta untuk sungguh-sungguh mengambil manfaat dari kegiatan pendampingan ini. Dan keempat Pemeliharaan pola-pola yang sudah ada. Kejujuran, keterbukaan, kemudahan akses, etika dan nilai yang baik dalam hubungan antara dosen dan mahasiswa tetap dipertahankan selama proses pendampingan ini.

Pendampingan pembuatan audiobook kosa kata bahasa Inggris yang sering digunakan dengan smart repetition dan brain wave dilaksankan pada pertengahan bulan Mei 2016. Kegiatan ini melibatkan partisipasi aktif 68 mahasiswa jurusan Hukum Ekonomi Islam (Muamalah), Fakultas Syariah dan Hukum UIN Walisongo.

Beberapa kendala selama pendampingan adalah susahnya dalam penyusunan database audiobook karena hal ini memerlukan ketelitian. Kesalahan dalam menyusun database, maka audiobook yang dieksekusi tidak akan memberikan hasil sesuai yang diinginkan ketika audiobook tersebut 
diputar dengan player digital. Kendala tersebut dapat diatasi dengan mengajak mahasiswa sering latihan dengan penuh kesabaran. Akhirnya mereka bisa membuat audiobook sendiri pada kosa kata yang ada pada Longman 3000.

Kendala yang lain adalah sering hang-nya aplikasi Telegram yang menyebabkan komunikasi antar peserta dengan peneliti terganggu. Hal ini terjadi karena sebelumnya peserta menginstall aplikasi WhatsApp di smartphone-nya. Aplikasi Telegram sebenarnya tidak terlalu berat, karena percakapan dan file yang terkirim tidak di simpan di memory phone, tetapi disimpan di Cloud Storage (penyimpanan virtual di internet), sedangkan WhatsApp tidak seperti itu, sehingga membuat smartphone full memory. Kendala tersebut dapat diatasi dengan men-delete data-data history yang ada di WhatsApp.

Hal lain yang dikeluhkan peserta file audiobook terlalu panjang durasinya hingga satu setengah jam jika diputar seluruhnya. Hal ini membuat peserta cepat bosan. Kendala ini diatasi dengan mendangarkan sebagiansebagian sedikit-sedikit, cukup 15 menit setiap harinya sambil rileks atau mengerjakan pelatihan mandirinya, dan memang seperti itulah praktek metode Spaced Repetition atau pengulangan berjeda agar hafalan lebih kuat dan lama.

Pada saat libur semester genap 2015/2016, sama sekali tidak terjadi komunikasi tentang pendampingan antara peserta dan peneliti. Hal ini terjadi karena kebetulan di dalam libur semester tersebut terdapat libur lebaran. Namun setelah libur tersebut, frekuensi komunikasi pendampingan berjalan normal kembali. Kondisi tetap tersebut harus diantisipasi, karena pendampingan akan berjalan terus sampai peserta lulus. Bila kondisi tersebut tidak diantisipasi, dikhawatirkan kegiatan pendampingan akan terhenti. Kondisi tersebut dapat diatasi dengan mengadakan perlombaan penguasan kosa kata secara online, audio confrence ketika libur kuliah, dan pemberian reward bagi peserta yang aktif berkomunikasi.

\section{KESIMPULAN}

Berdasarkan uraian dalam bab-bab sebelumnya dapat disimpulkan bahwa pembuatan audiobook dengan Smart Repetition dan Brain Wave Technology dilakukan bersama-sama para peserta dampingan. Pembuatan audiobook memang tidak mudah sehingga memerlukan latihan dan kesabaran peserta dampingan. Namun dengan seringnya latihan, akhirnya mereka dapat membuat audiobook sesuai dengan apa yang mereka inginkan.

Pendampingan penguasaan kosa kata bahasa Inggris yang sering digunakan dengan Smart Repetition dan Brain Wave Technology dengan 
beberapa tahapan. Tahap awal dilakukan dengan membangun komunitas menggunakan aplikasi Telegram, kemudian penyampaian materi pelatihan, dan interaksi terus-menerus antara peneliti dan peserta dampingan baik secara langsung maupun secara online hingga para peserta dampingan lulus kuliah.

Kesuksesan kegiatan ini memerlukan komitmen yang kuat dari peserta dampingan. Para peserta pendampingan harus bisa sungguh-sungguh memanfaatkan teknologi pembelajaran yang memang diinginkan berdasarkan hasil sharing dengan peneliti. Para peserta dampingan harus bahu aktif, saling mengingatkan dan memotivasi diantara para peserta untuk sungguh-sungguh mengambil manfaat dari kegiatan pendampingan ini Kejujuran, keterbukaan, kemudahan akses, etika dan nilai yang baik dalam hubungan antara peneliti dan peserta dampingan harus tetap dipertahankan selama proses pendampingan ini.

\section{DAFTAR PUSTAKA}

Abidin, Yunus, Metode Penelitian, Bandung: PT. Tarsito Bandung, 2009.

Arfan Rifqiawan, Raden, "Pembuatan Flash Card Digital untuk Pembelajaran 80\% Kosa Kata Al-Qur'an" dalam Jurnal at-Taqaddum UIN Walisongo, Volume 8, Nomor 1, Juli 2016.

Ebbinghaus, Herman, (tr. Ruger, Henry; Busenius, Clara), "Memory: $A$ Contribution to Experimental Psychology", Columbia University Press, New York, 1885.

Gunawan, Djohan. Kedahsyatan dan Kekuatan Gelombang Otak. Cet. I; Jakarta :

PT. Elex Media Komputindo, 2011.

Harmer, Jeremy, Longman Communication 3000, Longman Dictionary of Contemporary English Series, Harlow: Pearson Education, 2007.

LPM IAIN Sunan Ampel Surabaya, Modul Pelatihan Kuliab Kerja Nyata (KKN) Transformatif IAIN Sunan Ampel Surabaya, Surabaya : LPM IAIN Sunan Ampel, 2008.

Mustajib, Ajib. Rahasia Dabsyat Terapi Otak Audio MP3. Cet. I; Jakarta : Wahyu Media, 2010.

Spitzer, H.F., Studies in Retention, Journal of Educational Psychology,1939.

Zhuang, Tianbao, "A Study of Brainwave Entrainment Based on EEG Brain

Dynamics" in CSCE Computer and Information Science Journal, Vol. 2, No.2, May, 2009.

http:// www.carakita.com http://www.bwgen.com http://www.nextup.com

http://www.web.net/ robrien/papers/arfinal.html 